\title{
CHAPTER TWENTY-ONE
}

\section{REFLECTIONS}

1.

At the end of this History of the Dutch Opium Problem, it is good to realize that there were also Dutch people who criticized the imperial and colonial projects of the Dutch. In the 17 th-century one of the very few VOC intellectuals, Reaal, tried to change the dominant drive of his organization. Above, the famous dictum of Multatuli is quoted as one of the harshest judgments of the colonial regime. He was certainly not alone, but the criticism was often rather ambiguous.

Take the following quotation relative to the Dutch "public opinion" in Holland in the 19th and early 2oth-century. People who all were highly responsible for the colonial regime and its narco-military policy acted like they were characters from Multatuli:

The arguments of Dirk van Hogendorp [1761-1822], who called the opium monopoly one of the most hurtful and injurious features that dishonor the administration of the Dutch East Indies; of Minister of the Colonies Rochussen [1832-1912], who put opium on a line with the plague; of Minister of the Colonies Loudon [1824-190o], who classed it with poison; of Minister of the Colonies Sprenger Van Eyck [1842-1907], who spoke of its use as a great evil; of Minister of Colonies Keuchenius [1822-1893], who characterized it as a means to debauch and ruin the population-all these arguments could not prevail, even with those who brought them forward when their colonial politics needed some moral leavening, against the consideration that there is money in opium. ${ }^{1}$

This is an effective demonstration of the immanent hypocrisy of the Dutch colonial elite vis-à-vis opium. Scheltema from Yale University, who wrote this in 1907, concluded from this ambivalent behavior that the Dutch colonial spirit 'is the spirit of trade' and in italics: 'Trade before everything! ... at present no less than in the time of the East India Company ... a rather flimsy foundation ... not developed into something of broader conception, more in keeping with the great movement of expansion on principles ... a very limited circle of thought ...', and so on.

\footnotetext{
${ }^{1}$ J. Scheltema, p. 248; the life data in the quotation are given by me.
} 
As alternatives and worthy successors, attention turned to the Americans in the Philippines or the Japanese in Formosa. Part 5 is devoted to both "New Imperialists". Here it can be said that if they are the alternative to those old Dutch colonial rulers, we should not be surprised to be confronted with exaggerated arguments, concerning a change from bad to worse.

Scheltema suffered from a symptomatic ideological blindness. ${ }^{2} \mathrm{He}$ really thought that only the money-making of criminal individuals was the motor behind all the opium traffic and that the government only had to eliminate them to solve the opium problem. Notwithstanding his severe and honest criticism of the Dutch colonial leadership, it is remarkable that he did not conclude from this that colonialism or the colonial government was a main part of The Opium Problem. Therefore, he expected the solution to lie in new-style colonial governments.

It is, furthermore, untenable to accuse trade as such for creating "evil" (at present, similar critics use 'the market'). This resembles the medieval accusations of mainstream theologians. It avoids seeing another serious problem in the undermining of all trade through the widespread monopolization of trade (nearly a contradiction in terms). This made free trade impossible and, therefore, trade on an equal and normal basis of supply and demand with indigenous people.

Scheltema's main target was the Opiumregie. This was a monopoly institution par excellence. In his daily newspaper, the Bataviaansch Nieuwsblad (September 1902), he criticized the government for its 'hypocritical' and 'immoral' behavior. ${ }^{3}$ This led to his imprisonment for three months. He took revenge in his AJS article, which had a great impact in the international press at the time. It had repercussions in the Dutch Parliament in Holland as well. The colonial bureaucrats reacted, however, in the obvious way: those members of Parliament had no knowledge of the Indies and knew nothing about opium. A reduction of the opium con-

2 Idem, note p. 250, 251. J. Scheltema was born in 1855 in Macassar (Celebes) where his father was "president" of the local Court of Justice. He served the Dutch government in Singapore and elsewhere; became a journalist in 1883; editor of several papers in Java; in 1903 'imprisoned for the publication of some observations on the opium policy of the Dutch government, too true to be tolerated in a Dutch dependency'. After his release, he settled for a year at Yale University, and succeeded in publishing there a long article in a scholarly journal without any relevant academic background. Anyway, his article was apparently accepted in the AJS, because it aims to provide the American government with advice on how (not) to handle the opium problem in the Philippines.

3 J. Rush, p. 237. 
sumption or production of opium (heroin, morphine) and cocaine were not envisaged.

Not only in Scheltema's writings, but generally, the criticism was not directed at the monopoly position of state institutions: if there had been free trade in opium in the East Indies, the price of opium would have collapsed; the widespread knowledge of the connotation "opium = colonial repression" had seriously undermined this market thanks to the antiDutch sentiments.

2.

For a world history of opium, nothing is so important as the Dutch assault on the East. In hindsight, it remains, possibly, the only fact of world historical importance concerning the Dutch colonization of the East, as the Dutch slave trade was for the colonization of the Americas and Africa. Apart from some architectural locations of memory, nothing is left of the realm once proudly called the Dutch Empire.

There never was such a "thing": from the beginning to the end (16001949), the leading concept and practice of this venture was, indeed, exploitation in horror scenarios. The silences in between two events were only recuperation time.

The VOC was satisfied with a network of coastal settlements that interfered in the affairs of the indigenous powers in order to exploit the available worthwhile agricultural and mining products in exchange for opium and fear. A fleet effectively connected these settlements. The many massacres permanently created the fear on which the exploitation was based. The unexpected hongi trips to destroy agricultural products, in order to keep the monopoly price as high as possible and competitors at home, are the most symptomatic methods of the general exploitation; they were guerrillas against the indigenous peasants.

This imperial or hegemonic construction was the VOC's strength and weakness: it had no friends, and its enemies were weak. It perished largely through its own incompetence, internal corruption, antagonism between VOC Holland and VOC East Indies, as well as European wars (Napoleon). 
The substantial investments in capital and manpower the Dutch used in the East were only directed to the creation of "monopoly profits": quite symbolic for this was the highest possible price-setting of a worthless product like opium.

Profit-making (whatever its definition) was and is still inherent in every supply and demand situation in product exchange. Profit was also the aim of the VOC, EIC and all other European colonial ventures. However, they mostly had no products which were of interest to the indigenous Asian people: thus, there could be no normal trade, supply and demand. Only demand was left, with an iron fist.

To use this last instrument was "easy" because all of them nurtured the astonishing arrogance and dangerous presumption of having the right and ability to claim large parts of a foreign world as their own property. And all of them used the scum of the European nations to do their dirty work in the tropical environments. And all of them were harassed by serious internal corruption and criminality even from the point of view of current value systems like Protestantism and Catholicism.

There were, however, marked differences between VOC and EIC. First, there was a very short period of free (pirate) trade, symptomatically called "pre"-companies, in the VOC case. This lasted about a century and a half for the EIC, only about a decade of two for the VOC.

In the EIC case the whole project was organized in a dominant way by the British aristocratic elite; in the Dutch case mostly by petty bourgeois bookkeepers. A European so-called "civilizing mission"- whatever its meaning nowadays - was a leading British activity much earlier and longer, and rescued the English language from oblivion. The more "Catholic" Anglicanism was practically more tolerant than the fanatic Dutch Calvinists or die-hard Catholic Portuguese and Spaniards.

There was also the following main difference. Already in 1602 the powerful Calvinist VOC arrived on the imperialist scene. This was from the beginning a military-, state- and God-supported attempt to create lucrative opportunities for monopoly profit-making. It took more than a century before the English state started a relevant strong support of the EIC after which, indeed, colonization could begin.

Contrary to the EIC, the VOC had from the beginning all the traits of a national project with a strong military-royal influence to destroy The Enemy (= the rest of the world). Fanatically, it traded only according the 
principle "deliver your products, or I shoot" and the principle "I must have the monopoly position". The basic octroy (1602) fixed this position, which was confirmed time and again. The VOC, indeed, 'acted the part of the Prince' as a contemporary commentator remarked. In a memorandum of 1741 a future Governor-General of the Dutch East Indies, Imhoff, told his readers that the $\mathrm{VOC}$ was

no mere Merchant, but also represents the Power of the Dutch Nation, and that whereas it journeys and trades in the former capacity, it is in the latter capacity that it is established there; to achieve its true goals the Company must assure its existence in both capacities and on the strength of both capacities, so tightly is the political interwoven with the mercantile, and vice versa. ${ }^{4}$

This resulted in a continuous war against all European competitors and indigenous producers.

4.

The above formed the breeding ground for producing, trading and distributing on a large scale a product which was known to be bad for the health and mind of the users: opium. Before this, opium was either used only in medicine in Europe or medicine plus luxury in a very limited number of Middle Eastern or other Asian scenes (royal). The Portuguese used it as a present in order to smooth their trade. The Dutch continued with this but made something like a cash crop of opium (amphioen), with which they created The Opium Problem in world history. Opium was, however, much more than this.

Slavery and opium deliveries were the methods to keep a willing labor force available to do the heavy work in the fields and mines until far into the 2oth-century. Opium also had the "function": to keep the indigenous elite dependent. From the 166 os until about 1950 Asian opium was seldom shipped to Europe, but remained the most profitable Asian product and trade. The third function was: opium as a substitute for money and as product for barter (opium for pepper, etc.).

\footnotetext{
4 Quoted in R. Vos, p. 1.
} 
The Dutch were the first to discover all these advantages of opium, and they were the first to push opium into Asian countries on a massive scale. It was the model for the British Empire in its treatment of China. By doing this, the VOC became the unbeatable and first international narco-military power from about 1660 onwards, as it conquered the Portuguese along the Malabar Coast. This remained the case until 1800 when the English took over this "honorable job" and the Dutch had to accept a very profitable secondary position. They proved that the mutual opium competition of the European imperialists (mainly Dutch, English and French) formed the "engine" by which this could proliferate into the present world Opium Problem.

6.

Not only the external competition is important, but for the VOC so is the internal one. It concerns the internal mutual competition between Holland and the East Indies. The VOC and later the "state" elite in Holland were jealous of the VOC and "state" elite in the East Indies for the enormous capital one could accumulate there personally. This antagonism formed a strong internal dynamic for the Dutch leadership in this imperialist and colonialist venture. The latter, however, had a rather autonomous field of operation and profit, the inter-Asian trade. This was difficult to control by VOC Holland, which was concerned only with the voyages outward and home-bound.

The most pernicious project "to make peace" between both groups was the Amphioen-Opium Society. This brought both factions of the Dutch leadership and shareholders multi-million profits in the 18th-century, sanctioned by the House of Orange, one of its largest profiteers.

This constellation remained fully intact, was even perfected and more strongly legitimated, after the VOC perished through internal and external circumstances, and a new Dutch Colonial State was invented and established. Narco-military exploitation remained the leading practice and principle. This was immediately apparent in the House of Orange constructions and participation in the Royal Dutch Trading Society (in fact a much extended Amphioen Society) or (Royal) Billiton Mining Company and later in (Royal) Unilever and Shell. 
The post-VOC regime was in fact a construction of the Dutch, French (Napoleonic Holland, Daendels) and English (Raffles' occupation of Java). The result was a continuation of the VOC regime as occupier of the East Indies, but now aimed at a full occupation and colonization of the whole archipelago. The Dutch state itself became responsible and acted more extensively as narco-military occupier of the East Indies. The penetration with opium was now systematized and extended to all corners of this archipelago.

Around 1900 it was again extended by the world's largest coca leaf and cocaine production and trade and a state monopoly on the industrial production and distribution of opium (Opiumregie). Without doubt, there was no other product in the Dutch Asian history from 1600-1949 which can compete with this lucrative drug business. The end of this Dutch opium history was also the end of the Dutch influence in the world.

8.

"How the snake could bite in its own tail" is perfectly demonstrated in the Dutch opium history after 1950 . This cannot be discussed here, but a provocative view on the future could be the following.

Without its lucrative colonies, the Netherlands could continue its economic life largely as a harbor region of Germany. In the 1960s, a kind of cultural revolution took place in the Netherlands more than elsewhere, in the heavy smoke and smell of marihuana, hashish, opium, cocaine, LSD, mescaline and many other aphrodisiacs. They all were (and are, more or less) publicly available. ${ }^{5}$ And since the 1980 s the Netherlands has become known in Europe for a new market concept to provide consumers in special shops with nearly everything they need to forget the serious dullness, etc. of Dutch culture.

In the meantime the old rice, rubber and coca plantations in Tempo Doeloe were replaced by extensive hashish plantations inside Holland itself, and the original Dutch cocaine production is now replaced by extensive ecstacy (MDMA) and other chemical drug laboratories.

5 See H. Derks (ed., 1989), p. 215-225. 